\title{
ANTHROPOS
}

100.2005: 359-377

\section{A Ritual Resurgence in Eastern Indonesia}

\author{
R. H. Barnes
}

\begin{abstract}
At the invitation of the eastern Indonesian village of Leuwayang, three researchers returned to Kédang to observe a revised harvest ritual once thought extinct. The article contains consideration of recent political changes in Indonesia affecting religious expression, describes the village birthday celebration and the series of community rituals that were subsequently carried out over a three-day period in the original village site. There follows a summary of the nightlong chant accompanying the reciting of male genealogies of the village with an explanation of its references to legendary village history. An attempt is made to place the chant within the comparative study of ritual language. The conclusion briefly tries to situate the rituals in relation to villagers' preoccupations in the modern world. [Eastern Indonesia, Lembata, Kédang, ritual, religious politics, cultural revival and reinvention, ritual language]
\end{abstract}

R. H. Barnes, Professor of Social Anthropology, University of Oxford, Fellow of St. Antony's College, Oxford. - He has conducted extensive field research between 1969 and 2004 among the Kédang- and Lamaholot-speaking peoples of Flores, Adonara, Solor, and Lembata. - His publications include: Kédang. A Study of the Collective Thought of an Eastern Indonesian People (Oxford 1974); Sea Hunters of Indonesia. Fishers and Weavers of Lamalera (Oxford 1996); and numerous articles on eastern Indonesia.

In July 1998 together with Ursula Samely and Ruth Barnes I returned to Kédang at the eastern end of the island of Lembata in eastern Indonesia in response to an invitation of villagers of Leuwayang. We were invited to attend an annual harvest ritual which had been extinct when I first conducted research there from 1969 to 1971 and revived some years after that research. There were in fact two more or less independent events within a few days of each other. The first was a village birthday celebration staged in the new part of the village at the beach. This celebration was also an innovation subsequent to my first research. The second event, called a utan ("we [incl.]" or "I eat beans") was a complex of ceremonies which took place over three days and nights in the traditional village site high in the mountain.

\section{Some Preliminary and Background Considerations}

I am not in the position to describe all of the shifts in perspective and changes in personal relationships that may have contributed to reinstating a traditional ceremony which was once deemed to have disappeared for good. That there has been a change of attitudes is clear. In the 1960s, many Catholics and Muslims would have refused to participate on religious grounds. In 1998 they took part with no sign of inhibition whatsoever. What can be said, however, is that in the background are several significant shifts in the politics of religion in Indonesia. Religion has been a politically sensitive issue in Indonesia since the inception of the republic in 1945. It became acutely so following the attempted coup allegedly led by disaffected army officers with communist sympathies in 1965 and the subsequent slaughter of hundreds of thousands of persons. The official state ideology of pancasila prescribes belief in one God. In the aftermath of the coup attempt, the state, aided by the army, forced mass conversions to one of the recognized world religions. Those who did not convert ran the risk of being deemed communists. The late 1960 s, therefore, was a period of fear and religious 


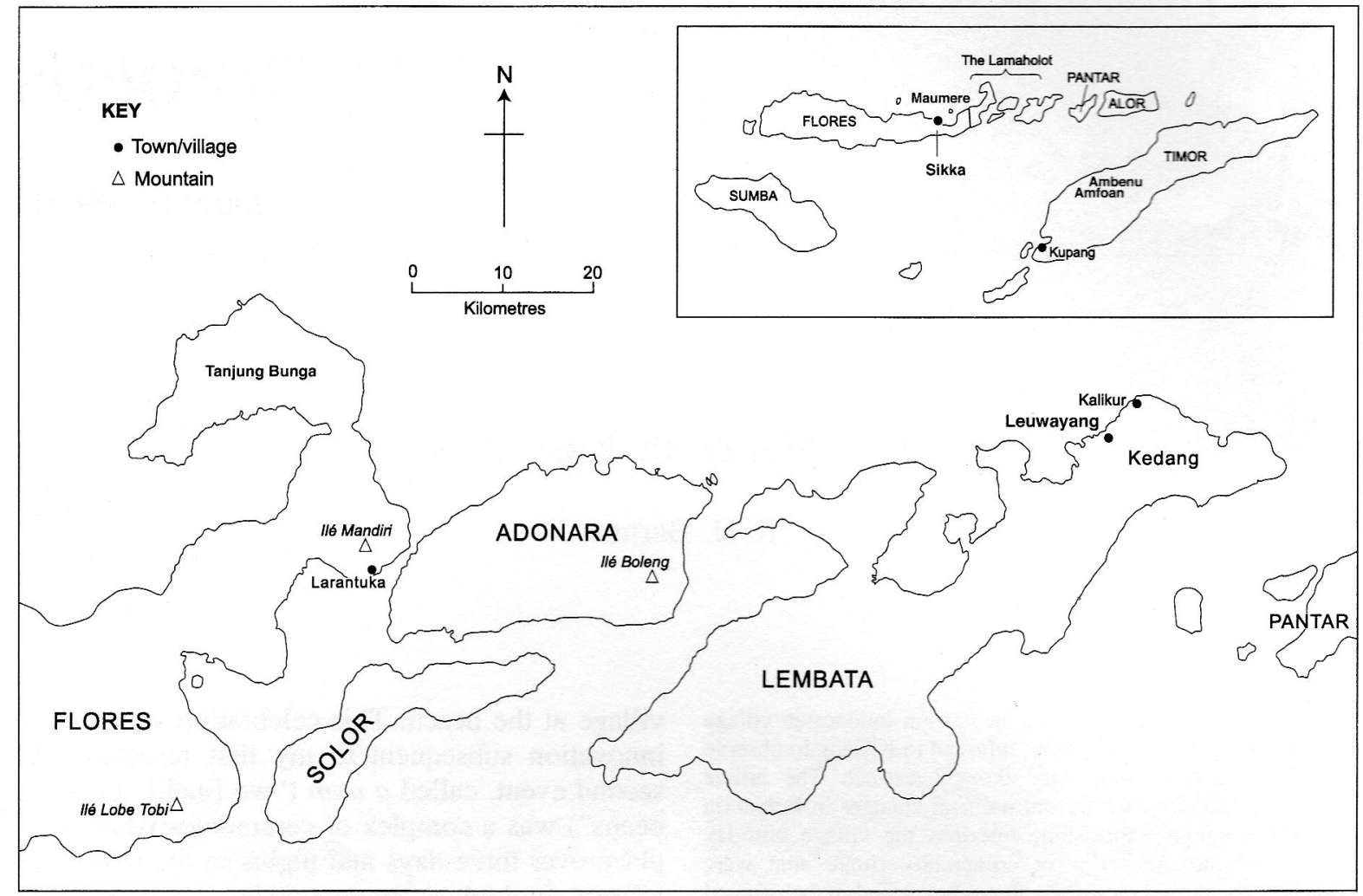

Map: East Flores and the Solor Islands

tension, an atmosphere which was not conducive to ceremonial cooperation amongst the various religious orientations. In the Flores region, including Kedang, the majority converted to Catholicism, although there were substantial conversions as well to Islam. In the village of Leuwayang a fraction held out and refused to convert to either religion.

At the period of my first research, those who held to the older ceremonial forms could do so only on an individual basis. Thus individuals might have ceremonies held for themselves releasing them from the prohibition on eating newly harvested crops, particularly beans, but there were no longer any collective rituals. Such persons were stigmatized (as indeed they still are) by government officials and others as kuno, "old-fashioned," orang primitip, "primitives" and officially classified as orang yang belum beragama, or "people who do not yet have religion." Villagers were frequently exhorted by officials to change their culture so that the village would become modern and to participate in development, development being the principal ideology of the Suharto dictatorship. Similar exhortations were also made of course by the expatriate and indigenous Catholic priests and by elements within Islam.
To a degree which I could not specify, attitudes toward traditional ritual have softened over the ensuing decades. At least governmental policy toward indigenous cultures has changed in various ways. Officials still distinguish between agama, one or other of the world religions, and adat or local custom or culture. The officially recognized religions are Catholicism, Protestantism, Islam, Hinduism, and Buddhism. Suharto's tacit support of Javanese mysticism or kebatinan represented in some eyes a deviation from official policy (Schwarz 2004: 171). At first Hinduism was not recognized as a religion because it lacked a high god and a sacred book. Balinese intellectuals and religious officials launched a campaign to gain recognition for their Hinduism as a religion, which was eventually successful in 1958 (Howe 2001: 5, 147-149). Some communities in the Tengger highlands of East Java came into contact with Balinese and eventually obtained recognition of their religion as Hinduism (Hefner 1985: 239-265; Beatty 1999: 219-235). Subsequently other peoples also converted their religious practices to Hinduism (Howe 2001: 150). In southern Borneo, the Dayak managed to obtain official recognition for their minority religion (Weinstock 
1987). I am not aware that there have been any such attempt in Kédang, where the vast majority accepted at least nominal conversion.

Local usage does not always oppose religion to adat. For example, anciently Catholic Larantuka, the capital of the East Flores Regency, regards Catholicism to be its adat (Dietrich 1997: 13). No doubt much the same could be said about Islam in Lamahala, Adonara, and elsewhere. Kipp and Rodgers (1987:3) have commented that in Java, Islam sometimes becomes adat. In a commonplace usage, adat is simply the cultural practices inherited from the ancestors which in certain ways distinguish a community from their neighbors or persons farther afield. Many an anthropologist has found it a very useful term for opening conversations or explaining research aims, whereas agama must be used with some care and is best avoided in Indonesia when explaining research objectives to officials, especially if your interest happens to be religious conflict.

Inspired by the successes in attracting tourism to Bali and Tanah Toraja Sulawesi, the Suharto regime began to encourage a process of commodification of culture.

With a view to "domesticating" ethnicity, the authorities suddenly took the bull by the horns, as it were. Regional cultural expressions, instead of being merely tolerated, were given active support in a way that was designed to take the wind out of the sails of any adherents of separatist ideas. One important symptom of this policy (albeit a relatively marginal one politically speaking) was greater tolerance of tribal traditions. But what must be striking to anyone visiting Indonesia recently is the well-nigh patronizing tendency to champion everything that in the government's view gives positive expression to the cultural pluralism of the country. It is hardly surprising that this patronage is selective, reducing what are in fact ethnic way[s] of life to folkloristic elements (Schefold 1998: 276).

Cultural performances for consumption by package tourists were organized with some success in the 1990s in East Flores and western Solor, before the economic collapse in 1997 and subsequent disruptions including the bombings of recent years, severely damaged the tourist industry. On Lembata the primary tourist objectives became the Ile Api region in the north and the whaling and fishing village of Lamalera in the south. Kedang is too remote to have ever exploited this potential form of income. Nevertheless, the positive valuing of local culture, even if only in a limited and tightly controlled, indeed manipulated, way, must have contributed to greater local self-confidence and in- deed renewed interest in questions about "who we are." The two events in Leuwayang in July 1998 were certainly in part celebrations of local identity, quite explicitly so in the case of the exhibitions and performances at the beach.

There is considerable literature on the relation between government and the performing arts and between government and culture more broadly in Indonesia, and of course in many other parts of the world as well. This is not the place to review that literature, but a brief indication of the variety of studies pertaining to Indonesia may be indicated; see for example Acciaioli $(1985,2001)$, Feinstein (1995), Hutajulu (1995), Lindsay (1995), Sutton (1995), and Yampolsky (1995). The effects of government intervention in the arts and local culture are various depending on period, on place, no doubt on personality, and of course on shifting government policy. The end of the Suharto regime brought a freeing of the communications media, a sharp diminishing of the surveillance of the population, reinvigorated party politics, and a return of grass roots political participation. Not all of the processes had completely worked themselves out by July 1998 , but the change was already making itself felt. People were much more open about expressing their views than they had been since 1965 . However, it must be remembered that the village birthday celebrations and the annual harvest ritual had been held for many years by 1998, so their constitution or reconstitution cannot be attributed to these at the time very recent changes.

\section{Village Birthday}

A young village head is said to have reinstated the harvest ritual in 1979. The reason for doing so was that the village felt that there had recently been too many deaths. In 1984, when Ursula Samely first witnessed it, it was a sparsely attended affair. The same village head instated the annual village festival in 1981. It was intended to mark the establishment of the official village (desa) of Leuwayang in 1960. This event in 1998 began on July 7th with a flag raising ceremony, formal speeches and some dancing, and a tug-of-war. The next evening was devoted to staged dancing. The program started at 6:00 in the evening. A temporary stage had been erected outdoors near the schoolhouse and chairs lined up for the audience. After a general introduction, a schoolteacher spoke a prayer and then read a long bureaucratic letter giving police permission to hold the event. Next a representative of the district officer gave a speech followed by 
another by the village head, Sotar Laleng of the clan Ape Utun. These speeches contained references to Kedang history and the need to revive culture (Ind., gali budaya kembali). Then a jury which was to judge the performances to come was sworn in and made to sign an oath one by one on stage. The stage was appropriately decorated with paintings of men and women in "traditional" adat clothing dancing in front of typical beach settlement panoramas.

There followed a presentation of genealogies from God down to the founding fathers of each village including Leuwayang. Then the actual performances began, a long series of groups from the various wards of the village performing more and less traditional songs and dances. There were some miscues and missteps, especially in the bamboo jumping dance where all the dancers eventually fell, but the best were very enjoyable. A new dance presented a group of women pretending to make crushed maize (the staple food) in unison accompanied by a bamboo zither and drum. The formalities ended about 11:30, and the free part of the agenda began, with people circle dancing until dawn.

Except for the imitation of making crushed maize the dances were traditional and commonplace Kedang dances with recognized names. Except for the very small number of visitors from outside, all of the members of the audience could just as well have been on stage singing and dancing. An irony of this performance of culture was the "traditional" costumes in a region which traditionally had a prohibition on weaving (Barnes 1974: 18). Many of the cloths used had been woven by Asma Pisang Ape Woren, who descends through her mother from the Ile Api region of Lembata which has been the traditional supplier of woven goods to Kedang. From her mother she learned how to weave. She is a skilled and innovative weaver, who experiments with natural dyes as well as instructs villagers in the techniques. At one time the elders of the village held a meeting in which they discussed the question of what the traditional cloths had looked like and then commissioned her to produce them for these performances. Many were also worn by the men and women attending the subsequent ceremonies in the old village. What she produced is quite unlike anything I had seen in my original period of field research there or on subsequent visits up to 1998. However, someone ignorant of Kedang history could easily be fooled into accepting that they represented a traditional weaving culture, because they are skillfully produced and attractive pieces, made with locally spun cotton thread and all natural dyes. Although it may be a brand-new tradition, in her hands it is definitely one to be appreciated (Barnes 2005). There were some delays as one group of performers replaced another, because she had not yet had time to weave enough cloth for all of the groups, so there had to be some hasty swopping of clothing behind a curtain between scenes.

On the following morning we attended an exhibition of local crafts, including basketry and cloth, in the school. The exhibition showed photographs and handicrafts organized on a variety of themes, including the burial practices of "heathens," a whole board devoted to photographs of the families Barnes and Samely, photographs and albums of Kedang people in Jakarta, Maumere, Flores, Malaysia, and elsewhere. This exhibition in its own way represented a form of cultural revival, because forms of basketry were available in abundance which were rarely to be seen thirty years before.

\section{A utan}

The new food ceremony was held in the Lèu Tuan, the old village site several hundred meters up the slope of the Kedang volcano. ${ }^{1}$ The events described in this and subsequent sections may be followed in the film "Ritual Reborn" (Barnes and Barnes 1999). We climbed to the site accompanied by friends on July 15 th. We were met at the very entrance by the priests, molan maran, Kewa Payong of Amun Toda clan, Aur Bala of >Iang Leraq clan, Laba Beda of Ape Woren clan and others and by a group of dancers. The lord of the land Tamal Beni of Ape Utun clan sprinkled us with water and then placed earth on our foreheads to reintroduce us to the spirit of the village.

After a rest we went up to the ceremonial center of the village, lèu puhe >alang ayaq (village center, center of the yard), where the first ceremony of that name took place, both Aur Bala and Kewa Payong chanting and sacrificing chickens at the same time. Lèu puhe is now surrounded by a low circle of stones and a low hedge, which had not

\footnotetext{
1 I employ here the phonetic conventions adopted by Samely and exemplified, for example, in her glossary (1991: 160225 , see specifically chap. 2 , especially p. 56 ). Vowels in particular are distinguished phonemically according to whether their pronunciation is breathy, produced by tongue root advancement, $(>\mathrm{a},>\mathrm{e},>\mathrm{e},>\mathrm{i},>\mathrm{o},>\mathrm{u})$ or not $(\mathrm{a}, \mathrm{e}, \mathrm{e}$, $\mathrm{i}, \mathrm{o}, \mathrm{u})$. For an extensive discussion of this unusual feature see Samely (1991:11-35). Consonants are notable for the phonemic glottal stop (q). The complete set is b, d, g, h, k, l, m, n, ng, p, q, r, s, t, w, y.
} 


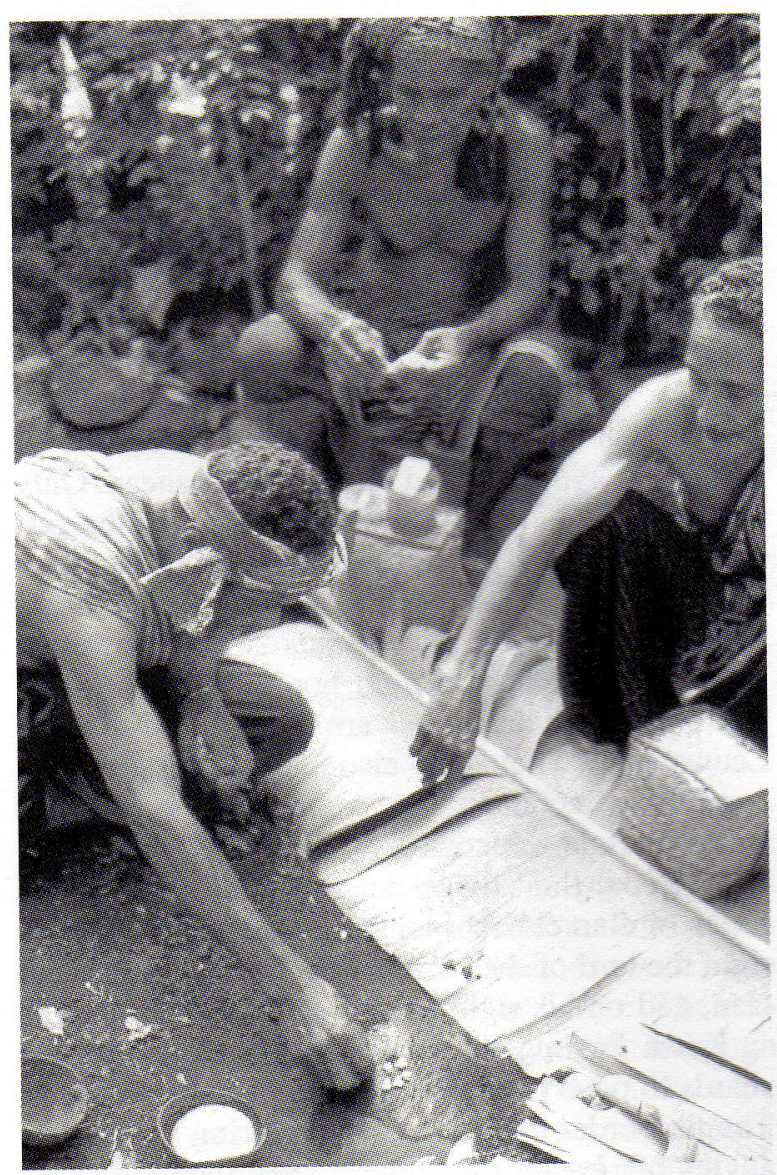

Fig. 1: Kewa Payong Amuntoda, Aur Bala >Iangleraq, and Laba Petang Bolileraq sacrificing at the village center (lèu puhe).

been the case years before. To the east were a smallish temple, huna $>$ ahar pati $>$ utang areq rian (house of ceremonial restrictions for paying the debt for women) and another, huna >ahar pati $>$ utang >anaq >abe (house of ceremonial restrictions for paying the debt for men). Beyond them, Aur Bala conducted the second ceremony, kala welong. Several chickens, a goat, and a pig were sacrificed for the first ceremony, some chickens and a goat for the second. A new and large village temple, huna hale (sacred house), ${ }^{2}$ had been built seaward of the village center. Later Kewa Payong went farther up the mountain slope to conduct a ceremony for koda, the genealogical descent line of the village. Then Kewa and Aur conducted

$\overline{2 \text { Huna hale }}$ translates into Indonesian as rumah berhala. Malay and Indonesian dictionaries translate rumah berhala as "idolatrous place of worship," which of course builds a religious judgement into the definition that I think may be lacking in local usage. It is interesting that Wilkinson $(1932: 27)$ cites a Malay source which so designates Catholic churches.

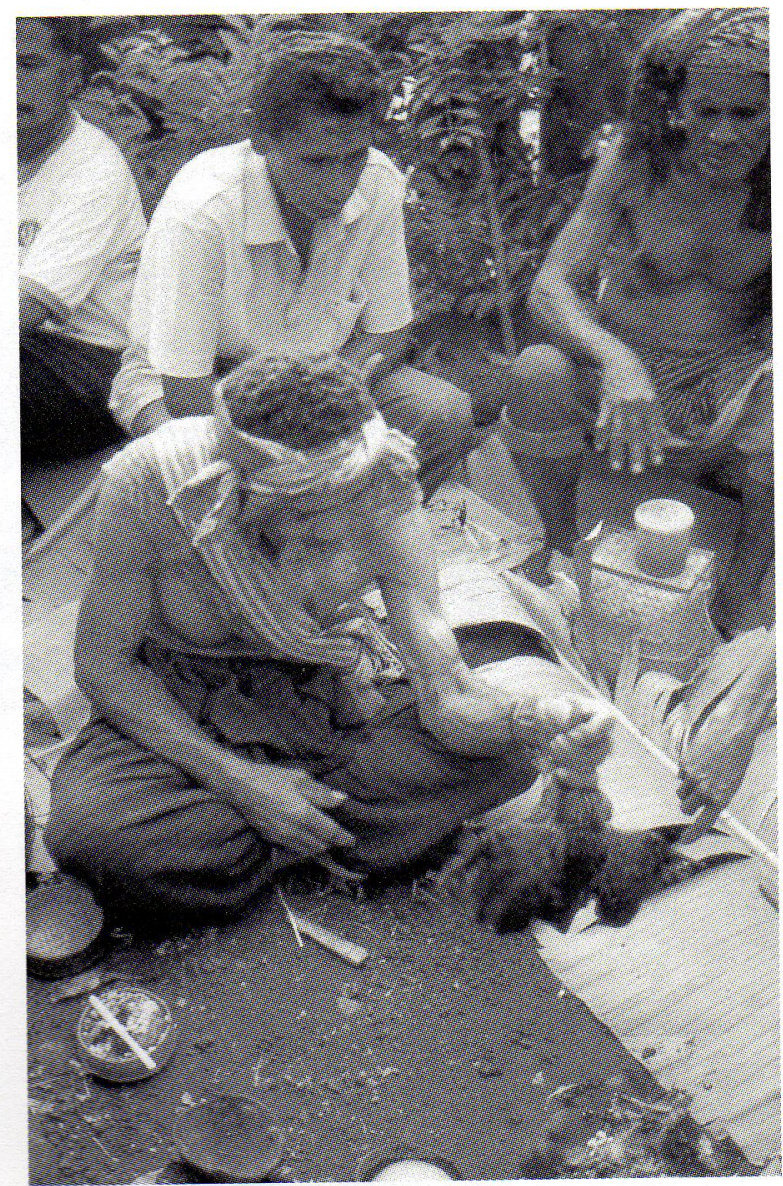

Fig. 2: Kewa Payong Amuntoda sacrificing a chicken.

a ceremony for the new village temple. After sacrificing some chickens to see if things would go well, they brought out a goat. They then dressed Kewa Payong's son Ledo Kewa, who was already wearing shorts, in a loincloth over his shorts. He took an Adonarese field knife and danced a war dance around the temple four times as prescribed by Kedang culture, travelling to the right, wana pan, as is also prescribed by the culture, before cutting the goat's head off with one blow (cp. Barnes 1974: $167 \mathrm{f} ., 188$ ). He had already pierced the goat's nostril to the brain with a sharp bamboo, and they had laid the goat ready on a stone. As soon as he had severed the head, another man grabbed the body and ran with it around the building, also travelling to the right, smearing blood on the house posts. Then Aur Bala conducted a ceremony sacrificing several chickens and another goat on the pile of stones nearby in which the warrior Nibang Narang's torso is buried. ${ }^{3}$

3 It may be useful to compare my original description (with tacit corrections): "At lèu puhe is a flat stone known as 


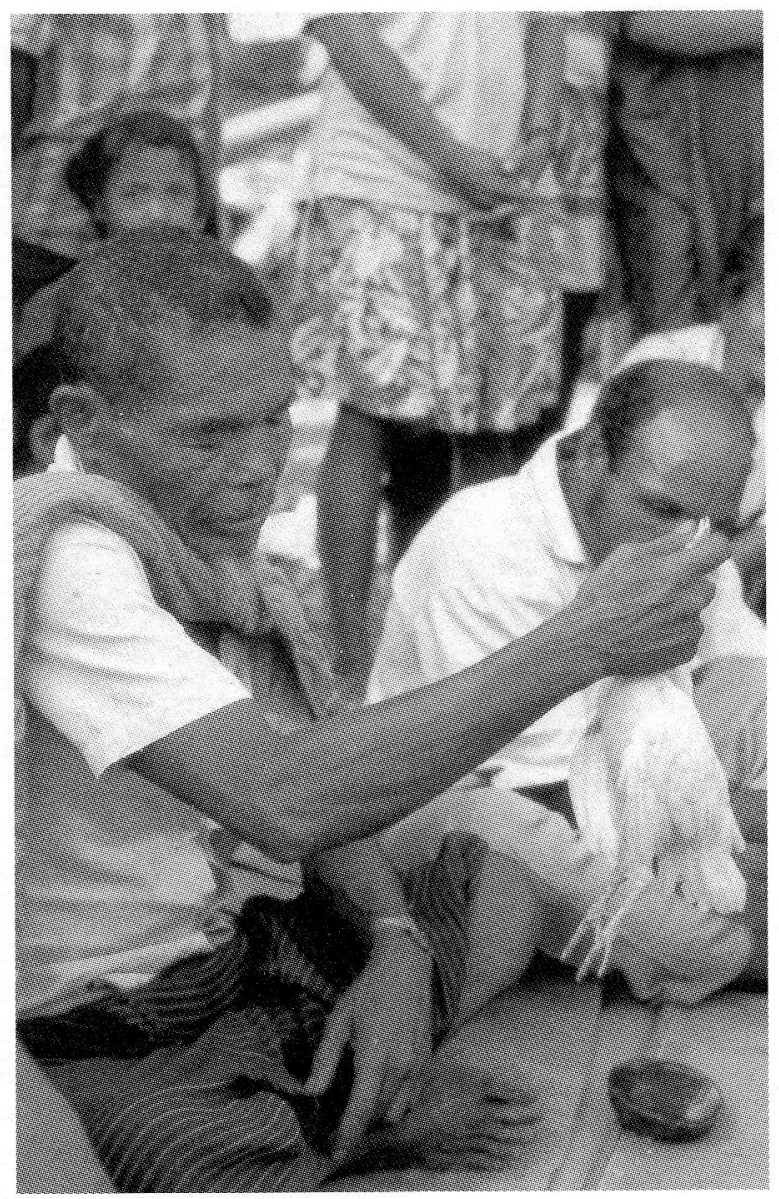

Fig. 3: Aur Bala >Iangleraq sacrificing a white chicken.

The day finished with huqi mapur (placing food on a ceremonial stone), the division of all the meat among the men only. The priests conducted ceremonies at the village center and fed the ancestors first. Then the priests were fed. The rest of the men and boys sat in a big circle nearby and waited patiently while large quantities of half cooked pig's meat, pig's blubber, roasted bananas, and cassava were distributed on banana leaves placed on the ground in front of them. Finally the signal was given to begin eating.

July 16th was a quiet day until the late afternoon, when preparations began. At 7:30 I joined

lapaq lèu, 'the village offering stone,' and near it a small circle of stones on the ground with an upright stone slab in the centre. This is called lado angin, and it is here that one makes rain offerings ... Just to the right of lado angin is the site of the former village temple, huna hale. Below it is a circular, though fairly flat, heap of stones about two metres in diameter, which is the grave of the torso of Nibang Naran, killed by Hoeq Rian in a war between Leuwayang and some villages near the present Leudanun" (Barnes 1974: 47). the men in the new village temple for the >ohong baheq ${ }^{4}$ in which the genealogies of the males are recited. Kewa Payong's son Ledo Kewa had rigged up an electric light in the temple powered by an electric generator which he had purchased on earnings from migrant labor in Malaysia and hauled up the mountain for this ceremony. Ursula Samely and Ruth Barnes had to stay with the women watching from outside, through the open walls. I was permitted to enter the temple through the entrance on the right side. Before I was allowed in, Kewa Payong rubbed dirt on my forehead. Only a few of the elders were seated then, but the rest soon joined them. I was seated in the middle of the seaward wall, the same side as the molan maran, who sat facing the pile of shards and sacrificial stones near the sacred right house post, lili wana. The two sacrificial stones are requested to protect Leuwayang. They can also punish people who commit infractions. The eventual seating order from the right door was Aur Bala, Kewa Payong, Laba Beda, the village head, myself, and then a series of clan elders, including immediately to my right the lord of the land, Tamal Beni of Ape Utun clan, and on his right Laba Petang of Boli Leraq.

Kewa Payong directed a man sitting near the shards to pour palm wine on the stones, lapaq lèu. The first order of business was placing small rectangles of rice on the stones. They then cut dried fish fins and tails and stuck them in the top of each rectangle. There were nine rectangles placed on the larger of the two stones, seven on the smaller. Most of the evening consisted in singing. That is to say the chanting was actually sung and was punctuated from time to time by solos from others and then general singing of the refrain. Aur Bala, Kewa Payong, and Laba Beda took turns chanting. They were accounting for all the genealogies (males only) down from God until the living. At about 10:30 Kewa directed that the bananas be roasted. Finally after around 12:30, they stopped and we had a meal of roast bananas and chicken mixed with shredded coconut. The village head told me that they had finished with the main genealogies and would now deal with the male children.

After we had eaten, Tamal Beni began singing the names of the recent men and then the children of Ape Utun. He was very hesitant and required

4 Defined, or better described, as "calling everything," the phrase refers to calling God and the ancestors to the ceremonial recitation of genealogy. Neither >ohong nor baheq have any meaning by themselves. Confusingly, and incorrectly, the phrase is sometimes pronounced ong bahe, with the translation "calling finished," but informed opinion denies that either this pronunciation or meaning is correct. 
Fig. 4: The new village temple.

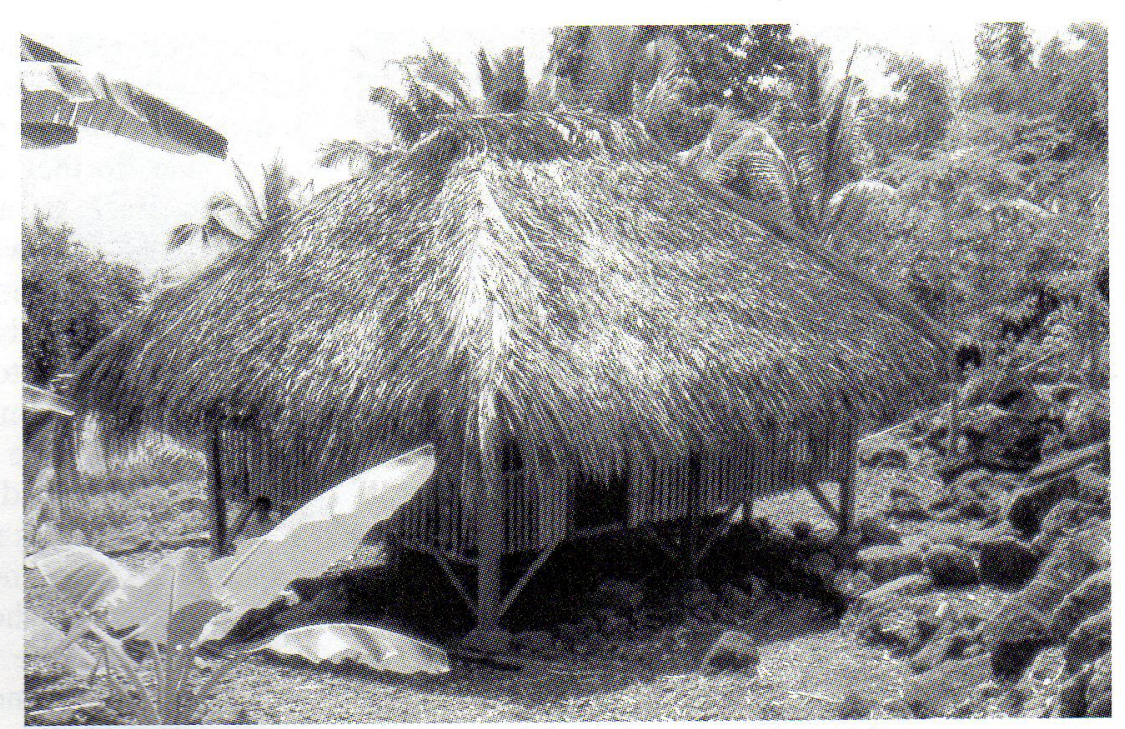

a lot of assistance. Except for the more frequent extemporary advice and help, this proceeded as before. He was through a little before 2:00. Then Laba Petang started on Boli Leraq. He was more fluent, but otherwise proceeded as before. The ceremony continued throughout the night, although we broke off after 2:30 and went to sleep. We were woken the next morning at 7:30 and rushed up for Amun Toda, the last clan. That finished about 9:30, and after a brief speech by Kewa Payong admonishing people to obey ancestral prescriptions, "the head must be above, the feet below," this phase finished about 10:30. That evening the women had their own distribution of chicken and pig meat, corresponding to that for men on the 15th, that is their own huqi mapur.

\section{Duaq haru}

On the morning of July 18th, the duaq haru ceremony for men took place. The expression duaq haru refers to rubbing medicine, such as chewed betel quid, on the chest and stomach of someone who is ill. In this case the substance to be used was the cooked new white beans mixed with rice. It took place at the small, men's temple. The three priests, plus the lord of the land and Laba Petang were inside the temple organizing the activities. They spread out the beans and rice mixture in flat baskets. Tamal Beni, the lord of the land, shaped rectangles (kokang) of the food and placed them in the center of each basket. He broke them off and rubbed them on the foreheads of each of the men in the temple and began the duaq haru. $\mathrm{He}$

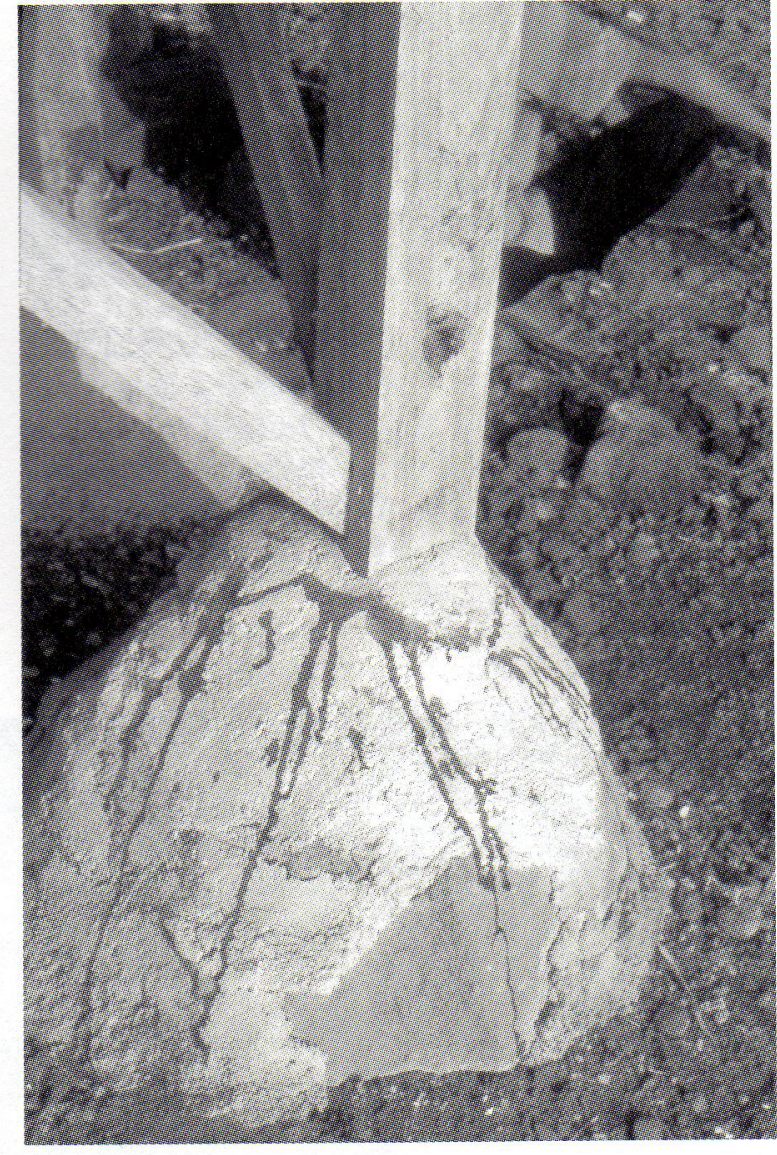

Fig. 5: Blood at the base of a post of the village temple.

stood up facing seaward and put the mixture on his forehead, then down his arms, body, and legs, before flipping the mixture off his fingers seaward. $\mathrm{He}$ did the same to each priest and subsequently to 


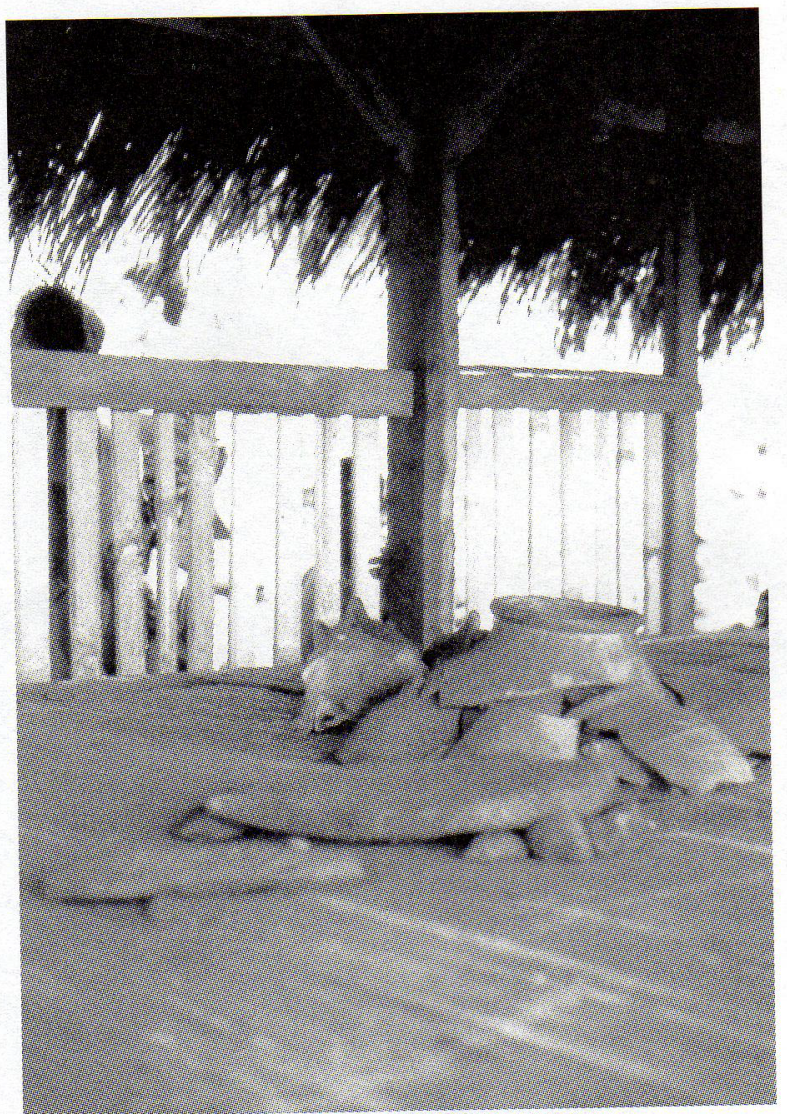

Fig. 6: Flat altar stones and potsherds in the village temple. representatives of each of the clans, who entered and left the temple for this purpose in turns. Sometimes the right person to represent a clan was not around, so they drafted in someone else from that clan. Each sat at the right house post facing seaward, and each was supposed to kick each foot seaward before getting up, although some did not. After that leaders distributed some of the mixture in three old bowls to the men who were present. Including the accompanying chanting, the whole episode did not take more than a half an hour.

Next they moved up to the women's temple, where the same was repeated for the women. During the men's ceremony, women could only look on from outside. The duaq haru for women was administered by the wife of the lord of the land, who looked on, sometimes giving instructions, as the women appeared less confident about what was expected. During the women's ceremony, it was the men who had to look on from outside. Once these ceremonies were completed, everyone in the village was free to eat the new crops. The formalities being over, the men and women went to the village clearing, where they commenced circle dancing, which lasted until about noon. In the afternoon after the heat of the day began to subside, we started down the mountain to the beach section of the village.

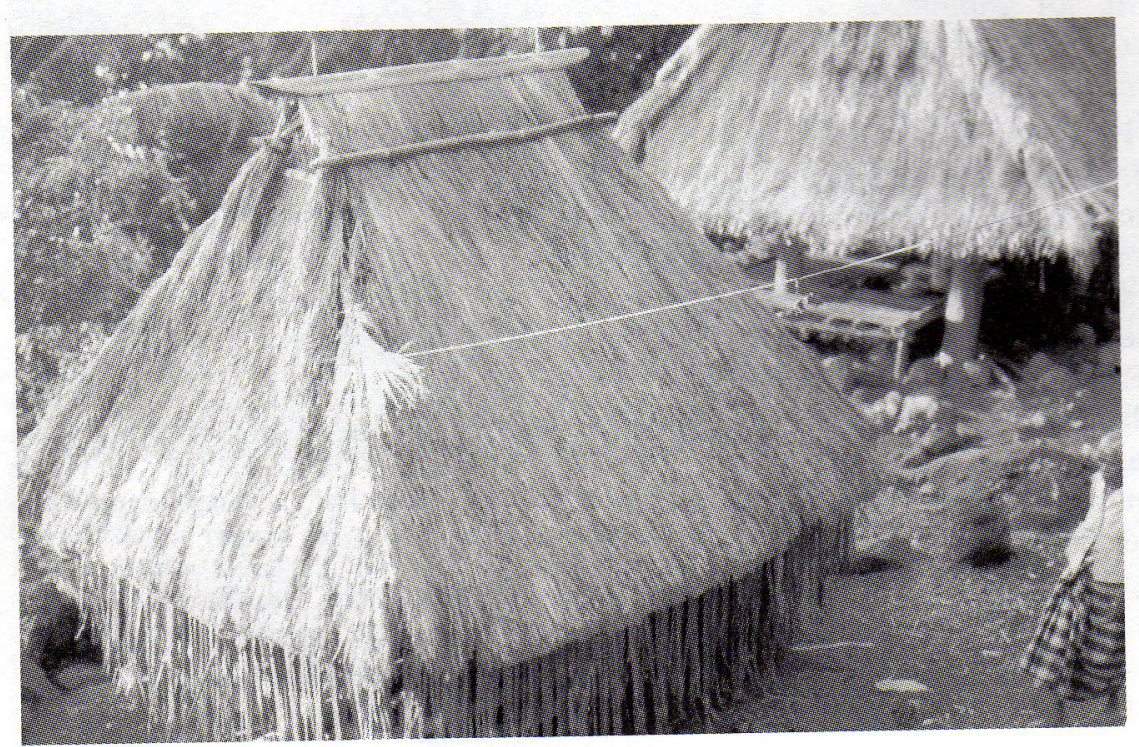

Fig. 7: The small temple for the ceremony for women. 
Fig. 8: Young women dancing.

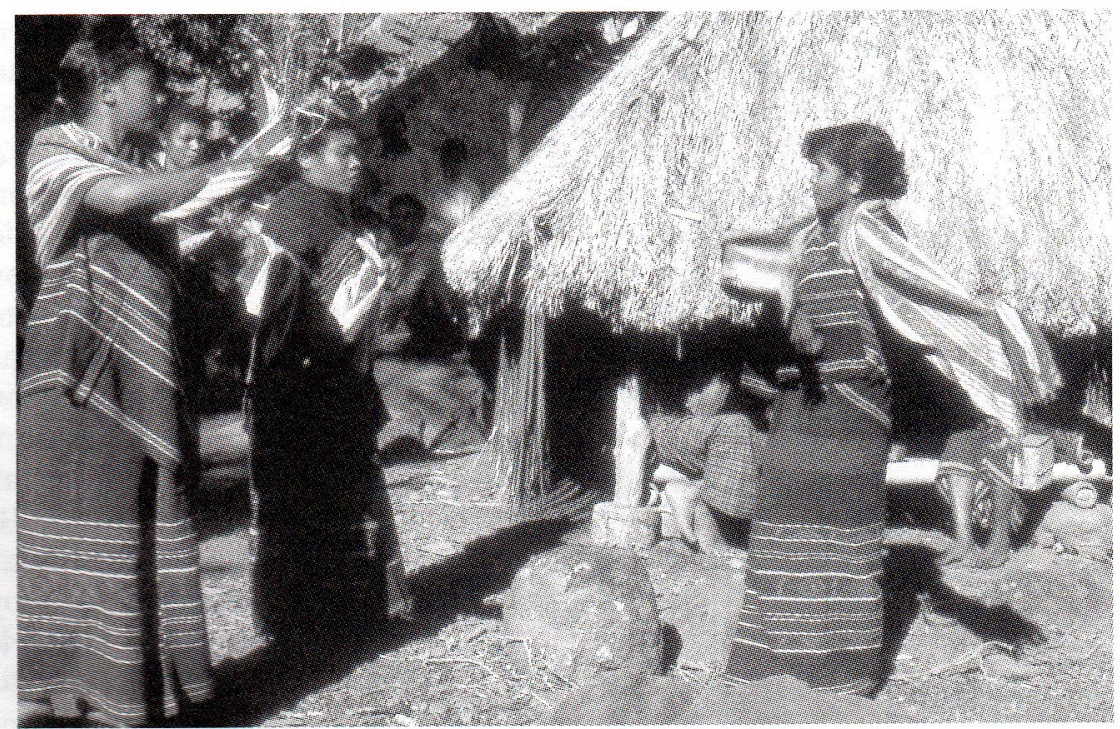

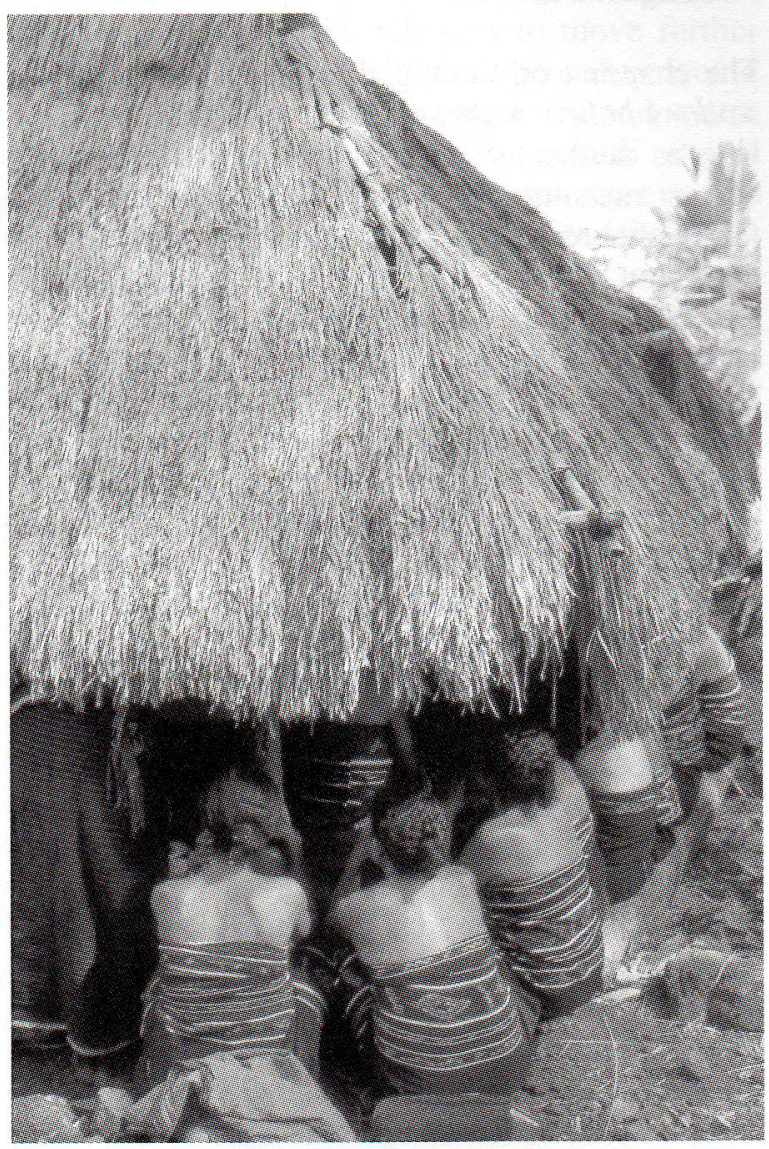

Fig. 9: Woman watching the women's duaq haru.

\section{Discussion}

When a community ritual is revived after a long hiatus, the question of its authenticity arises. In the period 1969-71, neither Aur Bala nor Kewa Payong were yet acting as priests. However, Aur Bala's father Bala Beyeng was then one of two active priests in Leuwayang, and both Aur Bala and Kewa Payong were very knowledgeable about Kedang cultural practices. Laba Beda, whom I have included as one of the priests, helped in the chanting and singing, but is not a fully functioning priest in the sense that he does not conduct sacrifices. Such innovations as these men may have introduced would, therefore, have been made in the context of thorough knowledge of local culture. The new village temple, for example, was constructed from large commercially available planks, rather than purely local building materials, such as bamboo, as would have been used in the past. Otherwise, however, the structure conformed to Kedang prescriptions. The spars in the roof were oriented with their base ends down, tips up. The horizontal beams in the frame travelled around the rectangle, so far as could be judged, with the tip ends and bases oriented to the rule "travel to the right." The whole of the structure was properly oriented in the Kedang quadrant of space, centering on the mountain peak. The ceremonially important right house post was on the mountainside and on the right side of the structure as seen by a person standing above it and looking seaward (Barnes 1974: 68-72). Thus the priests were sitting on the right, from that perspective, and on the seaward 
side, facing the right house post, where the altar stones and other ritual paraphernalia were placed, and beyond it the mountain. Furthermore, the spars in the roof were an odd number, as prescribed, on each side. The rice rectangles placed on the two altar stones were nine and seven. In 1998, I was reminded over and over again that certain things must be odd in number, while in ceremonies like those we witnessed certain actions must be done four times. Thus each chant in the >ohong baheq was repeated, if not actually in precisely the same wording, four times. Ledo Kewa danced around the village temple four times before cutting off the head of the goat. These uses of number illustrated the odd versus even opposition's association with the difference between structure and event and between component and articulation and in some contexts that between life and death (Barnes 1982: 14-19).

The potsherds placed near the altar stones were from the pot named Kila Rian. One account of Kila Rian is that in the original village of mankind at the top of the Kedang mountain there were two pots, referred to by the ritual name Rawe Rian Kila Rian. In my first period of research I encountered divergent views about these pots. One opinion was that Rawe Rian Kila Rian refers to one thing, undifferentiated by sex. Another tradition is that Rawe Rian was actually both a gold pot and also, for those who had the eyes to see these things, a young girl who was crying so that the pot overflowed with water. As the ancestors descended by stages from the top of the mountain, they brought the pot with them. When they settled in the current ritual center of the village, the pot turned into a spring, where there is none now. Then the spring fled from the village to its current location farther east because it was being defiled by pigs. Lemur Lale, an ancestor of the clans $>$ Iang Leraq, Buang Leraq, and Boli Leraq, took a loincloth from Labala (southwest Lembata), tariq Lewobala, and a woman's sarong from Mau Behiq, wela Maubehiq, to the spring Wèi Rawe as an offering to keep it from running farther away. The original pot is now located at the source of the spring, but cannot be seen. The second pot was supposed to be a man named Kila Rian. When it was brought down to the present site it was kept in the temple. Supposedly it used to be kept tied there with a rope made from the fibers of the areng palm to prevent it from going to the spring to cohabit with Rawe Rian (Barnes 1974: 58 f.).

There are divergent views too about how Kila Rian was broken. One former priest, Leu Ameq of the clan Boli Leraq, thinks that it was broken by the Amfoan auxiliary warriors on one of their two trips to Kedang to assist the Head Rian Baraq of Kalikur in his wars against villages of the interior (Barnes 2001: 285-288, 294-299). Guru A. Sio Amuntoda, who conveyed Leu Ameq's view to me, also told me a different story which he had heard. Someone whose name he had forgotten, but who he thinks is Bote Lemur (son of Lemur Lale) of > liang Leraq, was digging beneath a cassava plant when he discovered a pot, which said "dig carefully so you do not stab me." He discovered that there were actually two pots. One, Kila Rian, he left, the other, Rawe Rian, he took out and moved a little way away. Rawe Rian complained that it was too hot, loyo pari narang darang. Rawe Rian said to cover it with tariq Lewobala, wela Maubehiq. Rawe Rian was still too hot, so he moved it several times until placing it where the spring is now located. The next morning he saw that it had disappeared into the ground and that water was coming out. As for Kila Rian, it used to steal animals at night so they shot it with an arrow, breaking it.

\section{>Ohong baheq}

The chanting on the night of the 16th was of the >ohong baheq, a phrase which is difficult to translate, as neither of its component words has any current meaning. However, it has been translated for me as meaning "calling everything." During this chant, the ancestors are called to participate in a communal meal through the sacrifice, the history of humanity from its inception at the top of the Kedang mountain to the founding of each of the clans of Leuwayang is recited, the ancestors are appealed to in order to provide fertility and good health, and finally the genealogies of all males, including infants, of the village are recited. This is an exhausting undertaking, lasting throughout the night. Fortunately the chanting could be shared by three men, while the genealogies of each clan was cited by an elder of that clan.

The chant itself is highly allusive and presupposes a knowledge of the background story, which it does not explicitly detail. According to the story in Leuwayang, humanity first lived at the top of the Kedang mountain, $>$ Uyo Lewun or $>$ Uye Lewun. The original settlement consisted in the great village, Lèu Rian, and the small village, Lèu Ehoq. Lèu Rian is represented just below the peak of the mountain by an untidy rectangle of stacked up stones. I was twice taken there by Kewa Payong in September 1969 and November 1970. Unfortu- 
nately my photographs of the site were destroyed. Lèu Ehoq was below Lèu Rian in the crater of the extinct volcano. Here the first ancestors cleared fields and began to develop culture, including the prohibitions which have been passed to the living by them. They also expanded their numbers until it became necessary to disperse down the sides of the mountain and establish new village sites.

The first such site for the ancestors of Leuwayang was at "the head of the forest [or forested over field], the valley of èyèq trees," tuen tubar, èyèq dèlèr. The second was at "the flat place, the deer yard," nara napoq, ruha >alang. The third was the location called "inside the stone terrace wall, the stacked up stone wall, the flat land," dolu laleng, bote dolu, bai biri. The chanting mentions all three places, but not exactly in this order. The fourth location is said to have been "the place of mango trees, within the loboq trees," but in 1998 the priests omitted this location. Finally the villagers settled at Wayang Hoteng Ruba Lewaq, which is the site of the old village, Lèu Tuan, and the ceremonial name of Leuwayang (Barnes 1974:31-37). All of the original villages of Kedang have a second, ceremonial name, such as this one. Successive Dutch and Indonesian governments pressured the villagers to move further down to the beach settlement, where they would be more accessible to the government and where churches, mosques, schools, and health clinics were eventually established, a process more or less completed in 1970 when the village head Om Suda Apelabi ordered everyone living in the mountain to build a house at the shore, where they could stay when summoned. Over the decades the mountain hamlets have emptied out, although Lèu Tuan still has a good number of dwellings.

The priests recite only the names of males because although women are born into the patrilineal clan, the women leave it. In 1998 I asked when precisely a woman joins her husband's clan, given that bridewealth payments may well not be completed until after her death and the last may be paid by the grandchildren or great-grandchildren. The answer is in effect that she does not do so until the last payment in the series of payments which make up the total bridewealth obligation is made. Her children's patrilineage would then be able, but only then, to erect a one post ceremonial structure, huna lelang, for her. In that case, her natal clan would need to bring three chickens and a stalk of bananas. Her husband's clan would do the same. Guru Sio expressed the cheerfully patriarchal view that "the man stays in the clan, the woman stays in the home," >anaq

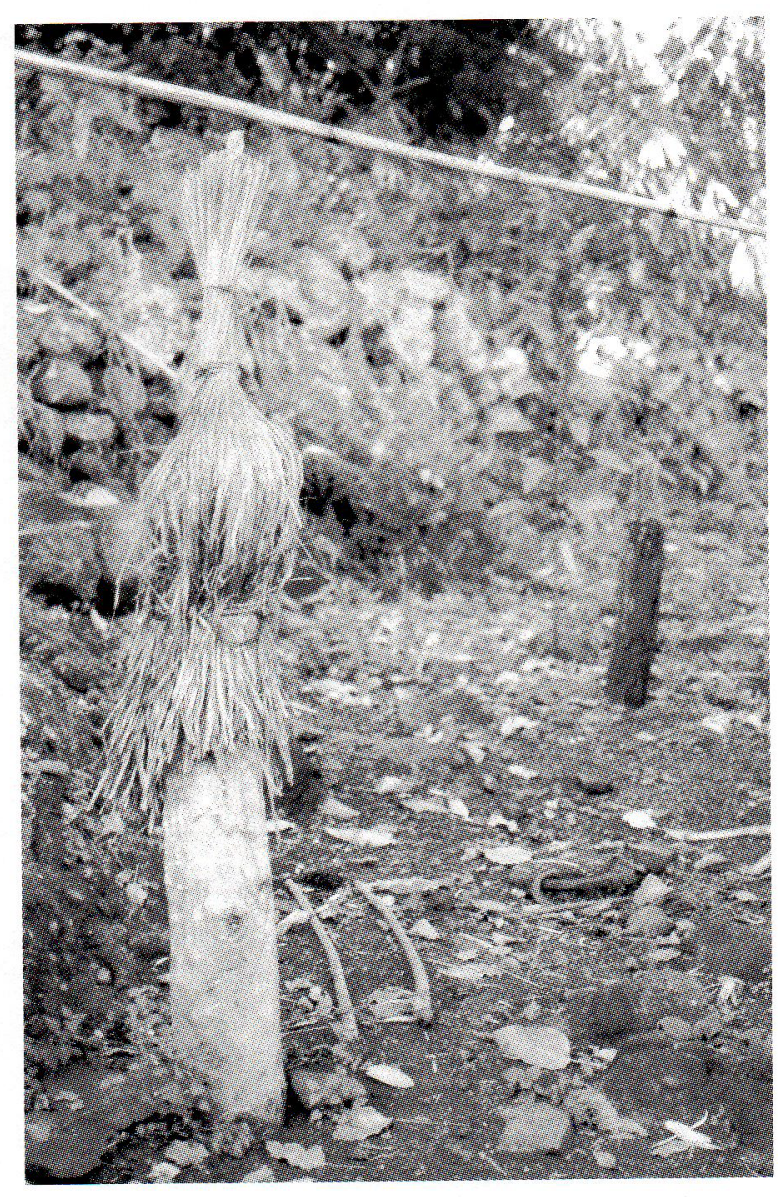

Fig. 10: A huna lelang or one post temple for an ancestress.

$>a b e$ puaq suku, areq rian puaq huna. Of course a woman enjoys considerable rights in her natal lineage, and her husband's lineage stands under multiple obligations to it throughout her lifetime and beyond.

The genealogy presented in Table 1 is extracted from the chanting of the night of July 16th. It can be compared with the genealogy of the founders of the clans of Leuwayang as I presented in 1974 (317) and repeated here as Table 2. The names in bold indicate discrepancies between the two genealogies. The chant began with an address to Amo Laha >Ula Loyo, i.e., Father Allah Lahatala Moon Sun. Lahatala is local Malay from Arabic Allah ta'ala, "God the Most High" and is found in one pronunciation or another throughout Indonesia. The principal native Kedang name for God is $>$ Ula Loyo, "Moon Sun," in a reversal of the "Sun Moon" expression found in many eastern Indonesian languages. In neighboring Lamaholot, "Sun Moon" as in Lera Wulan is commonly paired with the earth Tana Ekan to form a male/female deity or a male and a female deity comprising a unity. 
Table 1: Genealogy to the Founding of the Clans Recited in the >ohong baheq (1998).

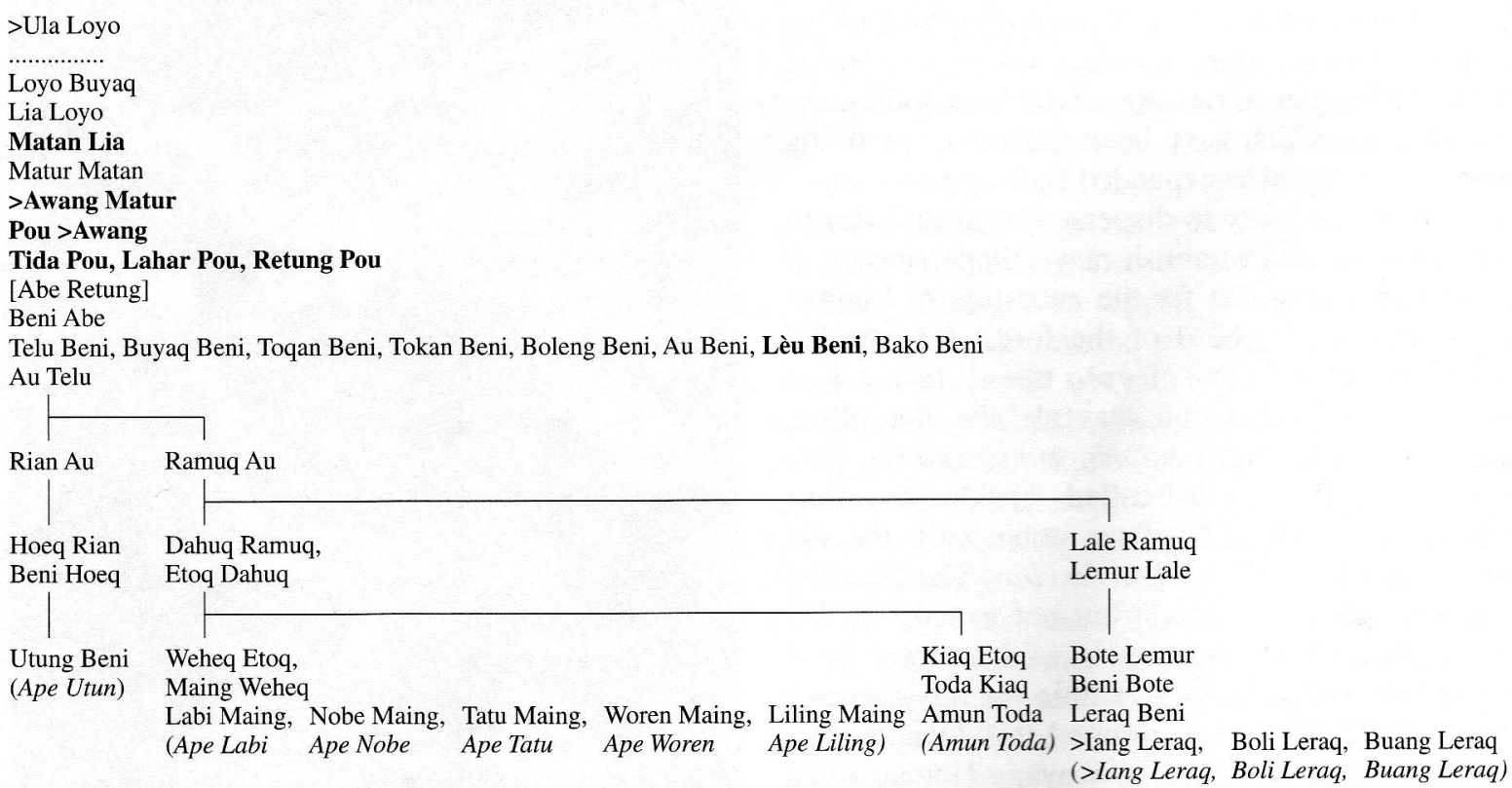

In the >ohong baheq, the priests paired Amo Laha $>$ Ula Loyo with Ino Welin Tuan Tanah, "Valued Mother, Lord of the Land," in which Tuan Tanah is Indonesian. The two lines were repeated four times before a series of names which I interpret as metaphors or alternative names for God.

\begin{tabular}{|c|c|}
\hline Beni Lewo Laha Loyo & $\begin{array}{l}\text { Beni Lewo, Maker of the } \\
\text { Sun } 5\end{array}$ \\
\hline Kila Loyo Madeng > Aman & $\begin{array}{l}\text { Kila Loyo, } \\
\text { >Aman }\end{array}$ \\
\hline Kila Rian Paiq Tuaq & $\begin{array}{l}\text { Kila Rian, Tapper of Palm } \\
\text { Wine }^{6}\end{array}$ \\
\hline
\end{tabular}

The following summarizes the events and activities alluded to in the chant. The above figures are enjoined to come down, place down the bow and the sword, place the rifle and power pouch at ready. Then there is a reference to breaking off the fin and tail fin of fish and putting down the rectangles of rice in sacrifice, which Kewa Payong had done before the chanting began. Another series of names follows, none of them direct ancestors

5 Alternatively Laha Loyo can be seen as a contraction of Amo Laha > Ula Loyo.

6 Kila Rian is sometimes known as Lia Rian. Lia Rian is sometimes viewed as an aspect of Divinity. The name also refers the morning star, as in the phrase lia keu paiq tuaq, "the morning star rises and taps palm wine." This phrase relates to a story of the morning star stealing a man's palm wine from the containers in the tree which collected the palm wine (Barnes 1974: 121). of the villagers of Leuwayang, but people who emerged from the earth at the top of the mountain.

Tuki Ai Mole Ai

Leto Kireq Wae Sara

Mole Elaq Haqi Longoq

Bukaq Keu Bokur Keu

Then the sky and the land are called, Lia Loyo (God) above is called upon to listen, >Ero Auq (God) below is told to hear. ${ }^{7}$ It is stated that the genealogies will be recited, that is, in effect, God will be informed of the living males of the clans and told by reciting the genealogies how they relate to the ancestors.

Koda ote wade ote

Relate genealogy

Deuq ote dewaq ote

The expression koda wade deuq dewaq is difficult to translate properly. The phrase means to relate genealogy and is literally "descent line, one cord." At the same time, koda is analogically closely associated with the peak of the mountain, where the original village of mankind is located. Deuq dewaq is formed by metathesis and reciprocal substitution from wadeq >udeq, i.e., "one cord," in this case a single line of male descent. It represents a form of "reversed language" at which older people used to be expert, in which reversed syllables disguised words.

$7>$ Ero Auq, i.e., the earth, corresponds to Lamaholot Tana Ekan. 
Table 2: Genealogy to the Founding of the Clans Collected 1969-1971.

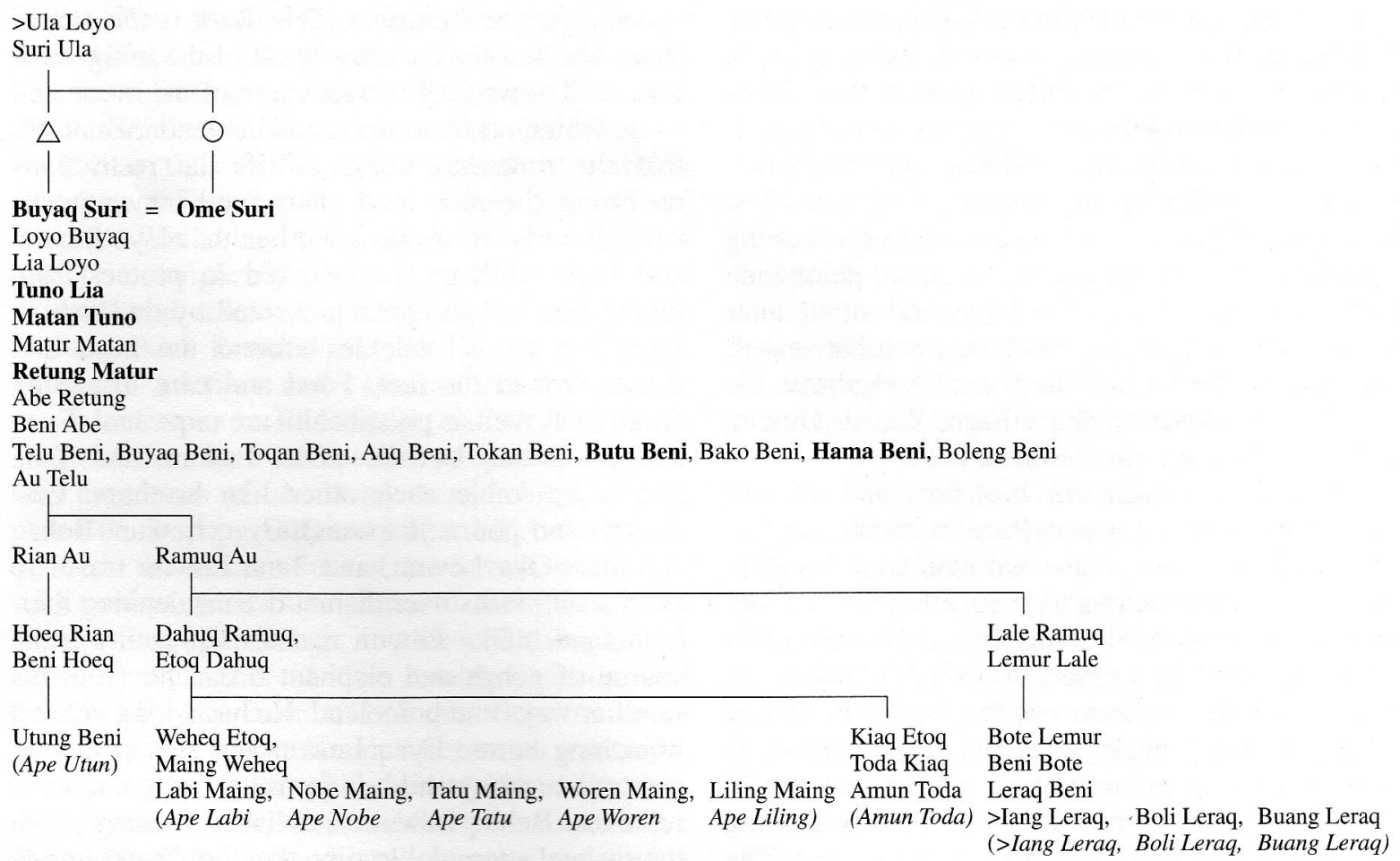

White Sun (Loyo Buyaq) is then implored to create human beings in the form of children, or perhaps he is described as doing so. Then the chant recites the descent line from Loyo Buyaq to Tida Pou, Lahar Pou, and Retung Pou.

$\begin{array}{ll}\text { Loyo Buyaq } & \text { White Sun } \\ \text { Lia Loyo } & \text { Lia Loyo } \\ \text { Matan Lia } & \text { Matan Lia } \\ \text { Matur Matan } & \text { Matur Matan } \\ \text { > Awang Matur } & \text { >Awang Matur } \\ \text { Tida sobe Pou >Awang } & \text { Tida descends from Pou } \\ & >\text { Awang } \\ \text { Lahar sobe Pou }>\text { Awang } & \text { Lahar descends from Pou } \\ & \text { >Awang } \\ \text { Retung sobe Pou }>\text { Awang } & \text { Retung descends from Pou } \\ & \text { >Awang }\end{array}$

It is a significant part of this section of the chant that there is a continuous line from divinity to the earliest ancestors. In my understanding, Loyo Buyaq, Lia Loyo, and perhaps Matan Lia are alternative names of God, in this case treated as though they formed a patrilineal line of descendants from >Ula Loyo. Thus just as elders merge with ancestors in local linguistic usage, the ancestors eventually merge with divinity. Next follows the establishment of the first village of mankind, Lèu Rian (Great Village) at the very peak and Lèu
Ehoq (Small Village) in the crater, at the top of the mountain where the teheq and hangol trees, the wild bananas and areng palms grow. The ancestors settle there and establish the borders of the community. Having established the original village, the ancestors open fields and tap palms in order to provide themselves with food and drink, while the population gradually increases in numbers. The ancestors engage in opening fields and awaiting the time to plant. Crops grow and an abundant harvest provides plenty to eat.

The sacred prescriptions on proper behavior laid down by the ancestors must be remembered. A request is made for protection from illness. There is a return to the topic of reciting genealogy and a request for as many offspring as possible. There follows a repeat of the statement that they are living in the original village at the top of the mountain and of the need to remember the ancestors' prescriptions. A reference is made to griefs and sorrows, such as those when crops fail, and the necessity of manufacturing salt in times of economic duress to provide some emergency income. Working the fields provides food to eat. A description is given of clearing a fallow field for planting and awaiting the time for planting and harvesting both for food and for seeds for the next planting crops such as beans and green gram. 
A short passage alludes to bridewealth negotiations. A request for blessing is made, followed by a description of building a house and erecting a temple. The spirits are called to erect the village and place the prohibitions. Again establishing of the borders is mentioned, followed by a repetition of building a house and erecting a temple. The large temple (that is the one the ceremony is being held in) contains large pots and bamboo palm wine containers, as well as the large and small altar stones. The village is established so that it will be secure. The basket sling is placed above the hearth. The names of the village, Wayan Hoteng and Ruba Lewaq, are mentioned.

There is a request for blessings and descendants. >Ulu Mado Aman Ratu, a name for Everyman, lives in his house and maintains his clan. The many inhabitants gather together for warmth and pull cloth around themselves at the mountain peak. An infant is carried in a cloth sling. A request is made for good health. Again the theme of relating the genealogy repeats. The mountain is compared to an upturned rice steamer and sieve. Six of the seven sons of Lewun Rian, including the mountain itself, $>$ Uyo Lewun, are listed. The list is as follows: Tana Lewun, $>$ Oka Lewun, Eyeq Lewun, Behaq Lewun, Gaya Lewun, $>$ Uyo Lewun. Missing from the list I recorded in my first visit are Kayaq Lewun and Rai Lewun. Included here, but not in my original list, is >Oka Lewun. My original information is that Gaja or Gaya Lewun was the ancestor of the Chinese and other Asians. Rai Lewun was the ancestor of Indonesians not living on Lembata. Tana Lewun was the ancestor of people living in the east, such as New Guinea. In another story, Tana Lewun was the ancestor of people living at the beach, who became the ancestors of the people living in Bernusa on the adjacent island of Pantar. Eyeq Lewun and Behaq Lewun were the ancestors of the animals, including the snakes, lizards, goats, pigs, and so on. In my original research, I did come across the name $>$ Oka Lewun from some sources, described as the ancestor of the spirits (Barnes 1974: 29). After more repetition, the original inhabitants are described as ignorant and dirty people of the interior who carry a basket to collect grasshoppers to roast and eat. This depiction alludes to a regional stereotype of people of the interior as uncultivated, slovenly people as opposed to sophisticated coastal dwellers. The spirits are described as living far away.

The brothers Tana Lewun, etc., are called from far to rest at the horizon and are requested to establish the village. God establishes custom (or culture). The rest of the brothers are also called for help in procreation. The ancestor Telu Beni appears for the first time. Telu Beni is the son of Beni Abe and the ancestor of all of the indigenous clans of Leuwayang. Observation of the moon and stars, which regulate the annual calendar, indicate that the time has come to lift the restrictions on eating the new food. This food may now be eaten in order to insure good health. $>$ Uyo Lewun and Behaq Lewun are invoked to protect from hindrances and danger represented by tied fishing lines and cords, shackles around the neck and stocks around the feet. Food and care in raising children as well as good health are requested. Eyeq Lewun, Behaq Lewun, >Oka Lewun, and Tana Lewun resemble each other like brothers. God divides and pours (disposes). Eyeq Lewun, Behaq Lewun, >Oka Lewun, and Tana Lewun travel to far distant places over distant oceans, leaving their homeland. >Oka Lewun reaches China-Jawa, the source of gongs and elephant tusks, far from his familiar ways and homeland. He has a long tail and branching horns. Eyeq Lewun and Behaq Lewun give rise to many children forming a community of relatives. Behaq Lewun establishes a village with houses and a temple. In time they hold a ceremony to eat the newly harvested foods.

After much repetition, a reference is made to storing culture and custom on the mountain, on the hill, and the protagonists acquire clothing, including hat, shirt, shoes, and an umbrella. The passage of time is counted until the date arrives for travelling and arriving. Confessions and admonitions are offered. The place of abode is left with culture and custom, food and drink, and with progeny. Buyaq Lewun is mentioned, with no obvious explanation why, unless, as seems probably, Buyaq Lewun is a name of Buyaq Suri, whose descendants are then recited from Loyo Buyaq to the three sons of Pou $>$ Awang. After much repetition, Retung Pou opens fields at the top of the mountain at tuen tubar, èyèq dèlèr. When harvest time comes there is food. He establishes the village at bote dolu bai biri and dolu laleng.

Next the sons of Beni Abe establish their villages. These sons are Lèu Beni, Boleng Beni, Tokan Beni, Au Beni, Telu Beni, Buyaq Beni, Toqan Beni, and Bako Beni, all of whom have many children. Of these names, only Lèu Beni did not appear in my original information from the first visit, while Butu Beni and Hama Beni, which I did acquire, did not appear in 1998. Of these names, Buyaq Beni founded the village of Leudanun immediately to the east of Leuwayang, while Toqan Beni founded Leu Toqan, a section and clan of the village Kalikur, and Au Beni 
founded the village of Leuhoeq, to the west. Tokan Beni founded Tokojain, a village in the Lamaholot speaking Ile Api region of northwest Lembata. Butu Beni founded Buton and Makasar. Bako Beni's son Koko Bako founded Bernusa on Pantar, thus in disagreement with the tradition that it was Tana Lewun who did so. Hama Beni founded Witihama, in eastern Adonara, a tradition which is completely unknown in Witihama where I conducted research in 2000 and 2001. Finally Boleng Beni founded the Ile Boleng region of southeast Adonara, and I surmise that this version too is unknown in Ile Boleng (Barnes 1974: 317).

Next the chant recites the names of the sons and grandsons of Lèu Beni, these being Lili Lèu, Aur Lili, Kopong Lili, and Lahar Lili, who do not figure in the descent lines of the current inhabitants of Leuwayang. It is emphasized that the sons of Beni Abe expand their families. Although they are dirty and ignorant, they establish custom and culture. Buyaq Beni and Toqan Beni move to Bunga Laleng in Leudanun. After much repetition, there is a request for rapid recovery from illnesses. The population increases and there is a request that discordances are not allowed to arise and divide the population. Descendants of Telu Beni increase as one generation replaces another. The ancestors of the principal clans of Leuwayang are named beginning with those of Ape Utun.

Once this point was reached, after a break for an evening meal, the priest and clan elders began the task of reciting the genealogies of the living males, back to these clan founders, one clan at a time.

\section{Language}

Speaking of the island of Roti southwest of Lembata, Fox (1971: 215) writes that, "Rotinese ritual language is a form of oral poetry characterized by the required coupling of virtually all semantic elements. The language is formal, formulaic, and parallelistic." He provides an extensive survey of semantic parallelism both worldwide, including importantly the Old Testament, and within Indonesia (Fox 1971: 215-219; 1988: 2-11).

Fox writes that on the eastern Indonesian island of Roti, the Rotinese do not use ritual language to communicate with the spirits and no clan histories are told in ritual language. Also "Rotinese have begun to dislodge individual recitation from collective performance." In Kedang, such language may indeed be used to add color to secular occasions, and some individuals have a reputation for skill in the language on such occasions, but
I know nothing of rivalries over such skills as occurs on Roti (Fox 1988: 19; 1971: 219-222). As opposed to Rotinese practice, in Kedang ritual language on the occasion of sacrifices and other ceremonies is used to communicate with the spirits. The chanting I have just summarized certainly does so. The spirits must be called to all such ceremonies. In Kedang tradition they are expected to attend funerals and accompany the deceased soul to the land of the dead. Thus it is said of a funeral in which these ancestors are not made an offering of food that the ancestors must return carrying their hands on their head, huneng ling, that is they hold the load of offered food stuffs on their head while walking, as women do when carrying loads, but there is nothing there but their hands. Ritual language is not used to recite history in any form as a straightforward narrative. In the chanting summarized above, an understanding of the relevant history of the village is taken for granted, but the various events in the population of the world are alluded to over and over again.

In the chanting I recorded, from around 19:00 until around 2:30 with breaks for a meal and some social singing, there are some 1240 lines before the genealogies of each of the clans was reached. When genealogical material and repetition is removed, there were 479 original lines, of which several were slight variations. The standard line consists of four words, usually two pairs of pairs, although with the edition of inconsequential words, such as "and" and "there" sometimes there are five-word and even six-word lines, and there was a single three-word line using a Lamaholot expression. A line is commonly paired with a second line conveying much the same information.
Ong >ote > ula loyo Wile >ole wero auq
The implication of this pair is that wherever the ancestors and spirits may be, they are being summoned to the sacrifice, recitation of genealogies and the accompanying feasts. In this linked pair of lines, there are four different kinds of binary pairs. Ong//wile are synonyms. >Ote//>ole are opposites. These two pairs link the lines by synonymy and contrast. > Ula//loyo, meaning "moon"//"sun" is a pair which in ordinary speech means either "sky" or "God". Like > ula//loyo, wero (or > ero)// auq is a recognized dyadic set (Fox 1971: $230 \mathrm{f}$.) composed of synonyms. In this case the two phrases >ula loyo and wero auq link the two lines by contrast. One could also say that the two lines are linked successively by verb, direction term, and substantive. 
Samely (1991: 101-115) has chosen to designate what Fox calls "dyadic sets" as "compounds." In investigating these matters, she found that the Kedang people she discussed it with expressed the view that "In Kedang, every word needs a friend". She explored a list of adjectives and discovered the "friend" for each of them, and similar experiments produced the same results for every other word she tried (107). In the >ohong baheq, there were 111 such recognized compounds or dyadic sets. In addition there were 281 pairs which, to my knowledge, do not have this status, although it is possible that I am mistaken and some do.

Fox (1971:248) tells us that in his eighteenthcentury publications on Hebrew poetry, Robert Lowth recognized, "1) synonymous parallels, 2) antithetical parallels, and 3) synthetic parallels." Fox suggests that Lowth's antithetic parallels could be further subdivided into complementaries, contraries, and contradictories. The overwhelming majority of the thousands of dyadic sets in Rotinese are synthetic. Samely's classification is even more detailed.

Compounds are lexical units which combine two or more bases to form what in all grammatical respects functions as a single word. Compounds can be described in terms of topic and comment, or theme and rheme, that is, given and new information. Underlying these terms is the concept that a compound word comprises two kinds of information. Given, or old, information is supplied by the head of the construction - the theme or topic while new information, modifying the theme in some way, is provided by the rheme. In English, the second element in a compound is usually thematic, while the focus rests on the first element: 'blackbird, "whitehouse. Used in a noun phrase, the two elements would constitute premodifier and head, and the placement of stress would be reversed: a black 'bird, a white 'house (Samely 1991: 101).

However, she notes that only some of the Kedang compounds, about $6 \%$, conform to this notion of compounds. The majority derives their overall meaning solely from the first of the two elements, the second element making no contribution to the resulting meaning of the compound. She distinguishes endocentric compounds, consisting of head and modifier or modifier followed by head, such as ai >api, "firewood," manuq tolor, "chicken egg," from exocentric, where neither of the two elements has the function of a semantic head, such as nèin hudeq, "breathe"//"support," meaning "hope" and ning mato, "nose"//"eye," i.e., "face." The exocentric compounds employ various parts of speech.
She notes that in Kedang, but not in, for example, Weyéwa, Sumba, compounds can be and are employed in ordinary language, but not all binary sets that appear in ritual language appear in ordinary language, an example being weheq//auq, in the following line:

ledo weheq pan auq

walk low, walk [on the] ground

Another category is single meaning compounds, illustrated by ai waq, "wood"//"stone," meaning either "trees" or "forest." Waq, "stone," in this case contributes nothing to the meaning. On the other hand, $a i w a q$ is one of a small number of cases where the two elements can be paired in either direction. Thus waq ai means "stone" and in this instance $a i$ is the noncontributing element. Samely lists ten such cases. Another is laen moleng, "sick"//"heal," meaning "ill," and moleng laen, meaning "recover," "heal." Samely divides these single meaning compounds into incompatibles and compatibles and further subdivides these two categories. Incompatibles she divides into "mere" incompatibles, where the sense relation between the two words does not permit classification ${ }^{8}$ contradictories which divided a conceptual domain into two mutually exclusive spheres, and contraries, where $\mathrm{X}$ entails not $\mathrm{Y}$, but not $Y$ does not entail $X$. The definitions of the last two categories are familiar from the formal logic of propositions. Further there are antonyms which do not strictly bisect a meaning domain, but permit grading in a region which may be covered by both terms, and reversives indicating motion or change in opposite directions. An example of "mere" incompatibles is tode hoyan, "in rows," "side by side"///"invite," "urge," "summon." She gives bita mate, "alive," "live"//"“dead," "die," meaning "alive," "live," as an example of a contradictory. Examples of contraries would include ruha wawi, "deer"//"pig," meaning "deer," > ula male, "moon"//"star," meaning "moon" and tiu waiq, "mouse," "rat"//"grasshopper," meaning "mouse" or "rat." It is much easier to find examples of contraries than contradictories. She gives as an antonym èmi pana, "cold"///"hot," meaning "fever." A reversive is bunuq dau, "descend"// "climb," meaning "descend."

\footnotetext{
8 Lyons (1969: $459 \mathrm{f}$.) distinguishes between incompatibles, such as red and green, and difference of sense, such as crimson and soft. Samely's "mere" incompatibility would seem to correspond approximately with Lyons's difference of sense, although Lyons notes the difference of sense does not necessarily imply incompatibility.
} 
Compatibles she classifies as having relations of identity, synonymy, bilingual synonymy (Indonesian - Kedang), bilingual synonymy (Kedang Lamaholot), hyponymy (roughly inclusion [see Lyons 1969: 453-455; 1977: 291-295]), verbal and nominalized form, cause and effect, action and effect, action and instrument, neighboring/parallel actions, interwoven actions, and finally sequence of actions. An example of identity that occurs in the >ohong baheq is peo peo, "hat"//"hat," meaning "wearing a hat." Examples of synonyms are toang banger, "wait"//"wait," meaning "wait," and mohoq mowar, "loosen"//"loosen," meaning "loosen." There were no examples of bilingual synonymy in the >ohong baheq. Samely gives as an example of Kedang/Indonesian synonymy puru larang, "prohibit" (Ked.)//"prohibit" (Indo.), meaning "prohibit." She gives as examples of Kedang/Lamaholot synonymy male tala, "star" (Ked.)//"star" (Lht.), meaning "star." She gives as examples of hyponymy bel baq, "cut," "chop"// "cut in two," meaning "cut" or "chop" and pedaq opeq, "bushknife"///"knife," meaning "bushknife." An example of verbal and nominalized forms is behar mehar, "to grind," "to mill"//" grinder," "mill," meaning "to grind," "to mill." An example of cause and effect is hopan hèng, "exhausted"// "short-winded," "pant," meaning "feel tired accompanied by panting." An example of action and effect relations in the chant is hoyoq leran, "to put in"///"have plenty of water," meaning "to put in." The action and instrument relation is exemplified by horan moran, "pile up rubbish"//"matter (soil, stones, grass) with which a hole is filled," meaning "pile up his rubbish" after clearing a field. Neighboring/parallel action is exemplified by $\mathrm{ka} \mathrm{min}$, "eat"//"drink," meaning to "eat." Interwoven action in the chant is shown by kaqar bitur, "burst," "split," "crack"//“lift," "raise," meaning "sprout." Sequences of action is demonstrated by bua kaban, "give birth"//"carry an infant, in a sarong slung over the shoulders."

The final set of pairs involves concealed relations in Samely's classification. In this arrangement, the first element conveys the meaning, while the second element is meaningless. Examples include tepi bolong, "look"//"?," meaning "look," >ahe toha, "improve"///"?," meaning "improve," doa tewel, "far"//"?," meaning "far," mai sopan, "stop"//"?," meaning "stop," bitol hewal, "uncover a little"//"?," meaning "uncover a little," loeng lereng, "inform," "report"//“?," meaning "inform," "report," iu daqa, "cook"//."?," meaning "cook," and many others. Samely mentions that some concealed relations compounds have constituents of only slightly different form, and example being hiroq haroq, "spill," "demolish"//"??," meaning "spill," "demolish." An example from the chant is kiol kaol, "love"///"?," meaning "love." Samely speaks of pairs in which neither element has any independent meaning independent of the whole phrase, of which riko rako, meaning "untidy," "messy" is an example.

There are a few pairs which I find difficult to fit into Samely's categories, suggesting that the categories might be expanded somewhat. Examples include two substantives which have some associated meanings, such as tahiq >angin, "sea"// "wind," meaning "sea" or "sea and wind," >ur nameq, "bow"//"arrow," meaning "bow and arrow," and wata nama, "shore"//"wide area," meaning "shore," although I suppose the first two might be deemed exocentric. Then there are near, but not absolute, synonyms, such as >iyuq nuaq, "saliva"// "phlegm," meaning "saliva," and kelung heaq, "replace"//"move out of the way," meaning "replace."

In time continued classification becomes uninteresting, however. What has been demonstrated has been anticipated by Lyons's comment that lexical opposites are of several different kinds $(1977: 271)$. It is also worth remembering that "gradable antonyms are frequently employed in everyday language-behaviour as contradictories rather than contraries", a case in point in Kedang being right and left, a contrast which depending on context is used either way, and that "ungradable opposites can, on occasion, be explicitly graded", "he is very much alive" (Lyons 1977:278). Unlike general social anthropological usage, Lyons confines complementaries to ungradable opposites (1977: 279). What is plain is that complementary opposites that carry a major symbolic importance in the culture, such as right/left, sky/earth, male/ female, inside/outside, wife-giver/wife-taker, are far from being the standard form of pairs which serve the purposes of ritual speech.

\section{Conclusion}

I hope in this article to have displayed something of the changing social and political context, and at the same time something of the cultural stability, of Kedang ritual life. I hope also to have helped to make manifest both sociological and linguistic features of a theme which others have demonstrated to be of widespread comparative significance both in Southeast Asia and worldwide, at the present and anciently, namely ritual language. Both the village birthday and the ceremonies around harvest 
continue to be celebrated annually. It should not be thought, however, that the community has turned its back on the modern world and retreated into an atavistic primitivism. People spend most of their time concentrating on making a living and they take a lively interest in new economic opportunities. Schools, the church, and the mosque continue to play their appointed roles in village life. Within two years, two of the young men we socialized with in the shore settlement were ordained as Catholic priests. These and other themes are worthy of anthropological attention. Nevertheless, it was a pleasure to witness an important institution about which I had heard much, but which was moribund at the time of my first encounter with Kedang culture. At the least the experience demonstrated that what is not currently present is not always permanently lost.

Research in 1998 was conducted with the aid of a grant from the British Academy Committee for South East Asian Studies and carried on under the auspices of the Indonesian Institute of Sciences. I thank these institutions for their support, as I do my many friends in Leuwayang.

I might mention in passing that I delayed producing this account of the a utan and >ohong baheq pending completion of a trilingual Kedang/Indonesian/English dictionary with Ursula Samely and with the assistance of Guru A. Sio Amuntoda and Om M. Suda Apelabi, which is now virtually finished. That work entailed further visits to Leuwayang in 1999, 2000, and 2001.

\section{References Cited}

\section{Acciaioli, Greg}

1985 Culture as Art. From Practice to Spectacle in Indonesia Canberra Anthropology 8: 148-172.

2001 "Archipelagic Culture" as an Exclusionary Government Discourse in Indonesia. The Asia Pacific Journal of Anthropology 2: 1-23.

\section{Barnes, R. H.}

1974 Kédang. A Study of the Collective Thought of an Eastern Indonesian People. With a Foreword by Rodney Needham. Oxford: The Clarendon Press.

1982 Number and Number Use in Kédang, Indonesia. Man 17: $1-22$

2001 Alliance and Warfare in an Eastern Indonesian Principality. Kédang in the Last Half of the Nineteenth Century. Bijdragen tot de Taal-, Land-en Volkenkunde 157: $271-311$.

\section{Barnes, R. H., and Ruth Barnes}

1999 Ritual Reborn. Kédang, Indonesia, 1998. Oxford: Educational Technology Resources Centre, University of Oxford.

\section{Barnes, Ruth}

2005 Moving between Cultures. Textiles as a Source of Innovation in Kedang, Eastern Indonesia. In: R. Barnes (ed.), Textiles in Indian Ocean Societies; pp. 150-162. London: RoutledgeCurzon.

\section{Beatty, Andrew}

1999 Varieties of Javanese Religion. An Anthropological Account. Cambridge: Cambridge University Press. (Cambridge Studies in Social and Cultural Anthropology, 111)

\section{Dietrich, Stefan}

1997 Kota Rénya, "Die Stadt der Königin". Religion, Identität und Wandel in einer ostindonesischen Kleinstadt. München. [Habilitationsschrift, Ludwig-MaximiliansUniversität München]

\section{Feinstein, Alan}

1995 Modern Javanese Theatre and the Politics of Culture. A Case Study of Teater Gapit. Bijdragen tot de Taal-, Land- en Volkenkunde 151: 617-638.

Fox, James J.

1971 Semantic Parallelism in Rotinese Ritual Language. Bijdragen tot de Taal-, Land-en Volkenkunde 127: 215255.

1988 Introduction. In: J. J. Fox (ed.), To Speak in Pairs. Essays on the Ritual Languages of Eastern Indonesia; pp. 1-28. Cambridge: Cambridge University Press. (Cambridge Studies in Oral and Literate Culture, 15)

\section{Hefner, Robert W.}

1985 Hindu Javanese. Tengger Tradition and Islam. Princeton: Princeton University Press.

Howe, Leo

2001 Hinduism \& Hierarchy in Bali. Oxford: James Curry.

\section{Hutajulu, Rithanony}

1995 Tourism's Impact on Toba Batak Ceremony. Bijdragen tot de Taal-, Land- en Volkenkunde 151: 639-655.

\section{Kipp, Rita Smith, and Susan Rodgers}

1987 Introduction. Indonesian Religions in Society. In: R Smith Kipp and S. Rodgers (eds.), Indonesian Religions in Transition; pp.1-31. Tucson: The University of Arizona Press.

Lindsay, Jennifer

1995 Cultural Policy and the Performing Arts in Southeast Asia. Bijdragen tot de Taal-, Land-en Volkenkunde 151: 656-671.

\section{Lyons, John}

1969 Introduction to Theoretical Linguistics. Cambridge: Cambridge University Press.

1977 Semantics. Vol. 1. Cambridge: Cambridge University Press.

\section{Samely, Ursula}

1991 Kedang (Eastern Indonesia). Some Aspects of Its Grammar. Hamburg: Helmut Buske Verlag. (Forum Phoneticum, 46)

\section{Schefold, Reimar}

1998 The Domestication of Culture. Nation-Building and Ethnic Diversity in Indonesia. Bijdragen tot de Taal-, Land- en Volkenkunde 154: 259-280.

\section{Schwarz, Adam}

2004 A Nation in Waiting. Indonesia's Search for Stability. Singapore: Talisman Publishing. 
Sutton, R. Anderson

1995 Performing Arts and Cultural Politics in South Sulawesi. Bijdragen tot de Taal-, Land-en Volkenkunde 151: $672-699$.

Weinstock, Joseph A.

1987 Kaharingan. Life and Death in Southern Borneo. In: R. Smith Kipp and S. Rodgers (eds.), Indonesian Religions in Transition; pp.71-97. Tucson: The University of Arizona Press.
Wilkinson, R. J.

1932 A Malay-English Dictionary (Romanised). Vol. 1. Mytilene: Salavopoulos and Kinderlis.

\section{Yampolsky, Philip}

1995 Forces for Change in the Regional Performing Arts of Indonesia. Bijdragen tot de Taal-, Land-en Volkenkunde 151: $700-725$. 